\title{
CONTACT INTERACTION OF A PREDEFORMED PLATE WHICH LIES WITHOUT FRICTION ON RIGID BASE WITH A PARABOLIC INDENTER
}

\author{
Hryhorii Habrusiev; Iryna Habrusieva
}

\author{
Ternopil Ivan Puluj National Technical University, Ternopil, Ukraine
}

\begin{abstract}
Summary. Within the framework of linearized formulation of a problem of the elasticity theory, the stressstrain state of a predeformed plate, which is modeled by a prestressed layer, is analyzed in the case of its smooth contact interaction with a rigid axisymmetric parabolic indenter. The dual integral equations of the problem are solved by representing the quested-for functions in the form of a partial series sum by the Bessel functions with unknown coefficients. Finite systems of linear algebraic equations are obtained for determination of these coefficients. The influence of the initial strains on the magnitude and features of the contact stresses and vertical displacements on the surface of the plate is analyzed for the case of compressible and incompressible solids. In order to illustrate the results, the cases of the Bartenev-Khazanovich and the harmonic-type potentials are addressed
\end{abstract}

Key words: predeformed plate, prestressed layer, contact stresses, vertical displacements, parabolic indenter, dual integral equations.

Introduction. Calculation of strength of structural elements and machine parts is one of the most important stages of their design. To assess the strength of contacting bodies, it is necessary to know the contact stresses and strains. Minimizing the calculation error requires taking into account the maximum number of factors that affect the contact interaction of bodies, in particular, the presence of initial stresses or strains.

The influence of initial stresses on the contact interaction of bodies under specific forms of elastic potential has been considered by many domestic and foreign researchers. In general, nonlinear elasticity theory is required to solve such problems. However, for large values of the initial deformations, it is possible to limit to a linearized setting. In particular, in [1] - a mathematical model to study the influence of the initial stress on the propagation of waves in a hollow infinite multilayered composite cylinder is built; in [2] - An asymptotic reduction method is introduced to construct a rod theory for a linearized general anisotropic elastic material for space deformation; in [3] - geometrically linearized theories for incompressible materials from nonlinear elasticity theory in the small displacement regime are derived. The article [4] provides a detailed review of the literature on contact problems for bodies with initial stresses or strains. Despite the increase in the number of studies on the contact interaction of bodies with a prestressed state, it should be noted that the problem of analyzing the interaction of indenters of complex configuration with a prestressed plate is still insufficiently studied.

The objectives of the article is to develop a method for determining the axisymmetric stress-strain state of a prestressed plate during its contact interaction with a rigid indenter and to investigate the influence of initial deformations on the distribution of contact stresses and vertical displacements of the boundary plane of the plate.

Statement of the problem. The formulation and solution of the problem will be carried out within the framework of the linearized formulation of the problem of the theory of elasticity. Consider a rigid indenter formed by rotating a branch of a parabola with parameter $R$ and a 
segment of a line that is perpendicular to the axis of the parabola and passes through its vertex around a common axis parallel to the axis of the parabola. The indenter is continuously without rotation and friction is pressed by a constant force $P$ into a pre-stressed layer of thickness $h$, which lies without friction on a rigid base.

Select a cylindrical coordinate system $(O, r, \theta, z)$ so that the coordinate plane $(r, O, \theta)$ coincides with the upper boundary plane of the layer, and the axis $O z$ - with the axis of symmetry of the indenter (Figure 1).

Based on the formulation of the problem, we can describe the function, the rotation of the graph around the axis $O z$ formed an indenter

$$
W(r)=\left\{\begin{array}{l}
0,0 \leq r \leq r_{a} ; \\
\frac{1}{2 R}\left(r-r_{a}\right)^{2}, r_{a}<r .
\end{array}\right.
$$

We consider the residual stresses present in the layer to be homogeneous. Therefore, the following expressions can be used for the components of the stress tensor and the displacement vector [5]

$$
\begin{gathered}
\sigma_{r z}(r, z)=-c_{31} \int_{0}^{\infty} \alpha^{3}\left\{A_{1} \operatorname{sh}(\alpha z)+A_{2}\left[s_{0} \operatorname{sh}(\alpha z)+\alpha z \operatorname{ch}(\alpha z)\right]+\right. \\
\left.+B_{1} \operatorname{ch}(\alpha z)+B_{2}\left[s_{0} \operatorname{ch}(\alpha z)+\alpha z \operatorname{sh}(\alpha z)\right]\right\} J_{1}(\alpha r) d \alpha \\
\sigma_{z z}(r, z)=c_{33} \int_{0}^{\infty} \alpha^{3}\left\{A_{1} \operatorname{ch}(\alpha z)+A_{2}[\operatorname{sch}(\alpha z)+\alpha z \operatorname{sh}(\alpha z)]+\right. \\
\left.+B_{1} \operatorname{sh}(\alpha z)+B_{2}[\operatorname{ssh}(\alpha z)+\alpha z \operatorname{ch}(\alpha z)]\right\} J_{0}(\alpha r) d \alpha \\
u_{r}(r, z)=-\int_{0}^{\infty} \alpha^{2}\left\{A_{1} \operatorname{ch}(\alpha z)+A_{2}[\operatorname{ch}(\alpha z)+\alpha z \operatorname{sh}(\alpha z)]+\right. \\
\left.+B_{1} \operatorname{sh}(\alpha z)+B_{2}[\operatorname{sh}(\alpha z)+\alpha z \operatorname{ch}(\alpha z)]\right\} J_{1}(\alpha r) d \alpha \\
u_{z}(r, z)=m \int_{0}^{\infty} \alpha^{2}\left\{A_{1} \operatorname{sh}(\alpha z)+A_{2}\left[s_{1} \operatorname{sh}(\alpha z)+\alpha z \operatorname{ch}(\alpha z)\right]+\right. \\
\left.+B_{1} \operatorname{ch}(\alpha z)+B_{2}\left[s_{1} \operatorname{ch}(\alpha z)+\alpha z \operatorname{sh}(\alpha z)\right]\right\} J_{0}(\alpha r) d \alpha
\end{gathered}
$$

The constants $c_{31}, c_{33}, c_{44}, m_{1}, n_{1}, l_{1}, s, s_{0}$, depend on the nature of the elastic potential and are selected in each case [5], and the unknown functions $A_{1}, B_{1}, A_{2}, B_{2}$ are determined from the boundary conditions of the problem.

On the upper boundary plane of the layer at $z=0$ from relations (1)-(2) we obtain

$$
\sigma_{z z}(r, 0)=c_{33} \int_{0}^{\infty} \alpha^{3}\left\{A_{1}+A_{2} s\right\} J_{0}(\alpha r) d \alpha
$$




$$
\begin{gathered}
\sigma_{r z}(r, 0)=-c_{31} \int_{0}^{\infty} \alpha^{3}\left\{B_{1}+B_{2} s_{0}\right\} J_{1}(\alpha r) d \alpha \\
u_{z}(r, 0)=m \int_{0}^{\infty} \alpha^{2}\left\{B_{1}+B_{2} s_{1}\right\} J_{0}(\alpha r) d \alpha
\end{gathered}
$$

On the lower boundary plane of the layer at $z=-h$ we have

$$
\begin{gathered}
\sigma_{r z}(r,-h)=-c_{31} \int_{0}^{\infty} \alpha^{3}\left\{-A_{1} \operatorname{sh}(\alpha h)+A_{2}\left[-s_{0} \operatorname{sh}(\alpha h)-\alpha h \operatorname{ch}(\alpha h)\right]+\right. \\
\left.+B_{1} \operatorname{ch}(\alpha h)+B_{2}\left[s_{0} \operatorname{ch}(\alpha h)+\alpha h \operatorname{sh}(\alpha h)\right]\right\} J_{1}(\alpha r) d \alpha \\
u_{z}(r,-h)=m \int_{0}^{\infty} \alpha^{2}\left\{-A_{1} \operatorname{sh}(\alpha h)+A_{2}\left[-s_{1} \operatorname{sh}(\alpha h)-\alpha h \operatorname{ch}(\alpha h)\right]+\right. \\
\left.+B_{1} \operatorname{ch}(\alpha h)+B_{2}\left[s_{1} \operatorname{ch}(\alpha h)+\alpha h \operatorname{sh}(\alpha h)\right]\right\} J_{0}(\alpha r) d \alpha .
\end{gathered}
$$

We will consider the radius of the contact area $a$ to be known. Then the boundary conditions of the problem are

$$
\begin{gathered}
\sigma_{r z}(r, 0)=0,0 \leq r<\infty ; \\
\sigma_{z z}(r, 0)=0, a \leq r ; \\
u_{z}(r, 0)=\omega(r), 0 \leq r \leq a ; \\
\sigma_{r z}(r,-h)=0,0 \leq r<\infty ; \\
u_{z}(r,-h)=0,0 \leq r<\infty .
\end{gathered}
$$

The function $\omega(r)$ describes the displacement of the points of the upper boundary plane of the elastic layer in the area of its contract with a rigid indenter. Therefore, based on the type of function $W(r)$, we can write:

$$
\omega(r)=\left\{\begin{array}{l}
\omega(a)-\frac{\left(a-r_{a}\right)^{2}}{2 R}, 0 \leq r \leq r_{a} ; \\
\omega(a)-\frac{1}{2 R}\left[\left(a-r_{a}\right)^{2}-\left(r-r_{a}\right)^{2}\right], r_{a}<r \leq a .
\end{array}\right.
$$

Solving of the problem. Requiring the fulfillment of the boundary condition (8), from equation (4) we obtain the relation between the functions $B_{1}$ and $B_{2}$ 


$$
B_{1}+B_{2} s_{0}=0 ; \Rightarrow B_{1}=-s_{0} B_{2}
$$

Substituting (14) into the relations (6) - (7) and satisfying the boundary conditions (11)(12), we have a system of equations with respect to unknowns $A_{1}$ and $A_{2}$

$$
\left\{\begin{array}{l}
A_{1} \operatorname{sh}(\alpha h)+A_{2}\left[s_{0} \operatorname{sh}(\alpha h)+\alpha h \operatorname{ch}(\alpha h)\right]=B_{2} \alpha h \operatorname{sh}(\alpha h) \\
A_{1} \operatorname{sh}(\alpha h)+A_{2}\left[s_{1} \operatorname{sh}(\alpha h)+\alpha h \operatorname{ch}(\alpha h)\right]= \\
\quad=B_{2}\left[\left(s_{1}-s_{0}\right) \operatorname{ch}(\alpha h)+\alpha h \operatorname{sh}(\alpha h)\right] .
\end{array}\right.
$$

Having solved (15), we obtain expressions for $A_{1}$ and $A_{2}$ through the function $B_{2}$

$$
A_{1}=-\frac{\alpha h+s_{0} \operatorname{sh}(\alpha h) \operatorname{ch}(\alpha h)}{s^{2}(\alpha h)} B_{2} ; \quad A_{2}=\frac{\operatorname{sh}(\alpha h) \operatorname{ch}(\alpha h)}{s^{2}(\alpha h)} B_{2} .
$$

Taking into account relations (14) and (16), expressions (3) and (5) take the form:

$$
\begin{gathered}
\sigma_{z z}(r, 0)=c_{33}\left(s-s_{0}\right) \int_{0}^{\infty} \frac{\alpha^{3} B_{2}}{\Delta(\alpha)} J_{0}(\alpha r) d \alpha ; \\
u_{z}(r, 0)=m\left(s_{1}-s_{0}\right) \int_{0}^{\infty} \alpha^{2} B_{2} J_{0}(\alpha r) d \alpha ; \\
\Delta(\alpha)=\frac{\left(s-s_{0}\right) s h^{2}(\alpha h)}{\left(s-s_{0}\right) \operatorname{sh}(\alpha h) \cdot \operatorname{ch}(\alpha h)-\alpha h}=\frac{\left(s-s_{0}\right)\left(1-2 e^{-2 \alpha h}+e^{-4 \alpha h}\right)}{\left(s-s_{0}\right)\left[1-e^{-4 \alpha h}\right]-4 \alpha h e^{-2 \alpha h}} .
\end{gathered}
$$

Having satisfied the boundary condition (9), on the basis of (17) we have

$$
c_{33}\left(s-s_{0}\right) \int_{0}^{\infty} \frac{\alpha^{3} B_{2}}{\Delta(\alpha)} J_{0}(\alpha r) d \alpha=0, a \leq r
$$

We introduce an unknown function $x(r), 0 \leq r \leq a$, with which we extend relation (19) for the interval $0 \leq r<\infty$

$$
c_{33}\left(s-s_{0}\right) \int_{0}^{\infty} \frac{\alpha^{3} B_{2}}{\Delta(\alpha)} J_{0}(\alpha r) d \alpha=x(r) \eta(a-r), 0 \leq r<\infty,
$$

where $\eta(r)$ is Heaviside function. 
The function $x(r)$ determines the distribution of contact stresses under the indenter. Given their continuity, as well as the absence at the boundary of the contact area (at $r=a$ ), we present $x(r)$ in the form of a segment of a generalized Fourier series by functions $J_{0}\left(\frac{\lambda_{n}}{a} r\right)$

$$
\sigma_{z z}(r, 0)=x(r)=\sum_{n=1}^{N} a_{n} J_{0}\left(\frac{\lambda_{n}}{a} r\right), 0 \leq r \leq a,
$$

where $\lambda_{n}, n=\overline{1, N}$ is positive roots of the Bessel function $J_{0}\left(\lambda_{n}\right)=0 ; a_{n}$ is nknown coefficients.

Applying the formula for inverting the integral Hankel transformation to relation (20) and taking into account representation (21), we obtain

$$
\begin{gathered}
\frac{\alpha^{2} B_{2}}{\Delta(\alpha)}=\frac{1}{c_{33}\left(s-s_{0}\right)} \int_{0}^{a} r \sum_{n=1}^{N} a_{n} J_{0}\left(\frac{\lambda_{n}}{a} r\right) J_{0}(\alpha r) d r= \\
=\frac{1}{c_{33}\left(s-s_{0}\right)} \sum_{n=1}^{N} a_{n} \int_{0}^{a} r J_{0}\left(\frac{\lambda_{n}}{a} r\right) J_{0}(\alpha r) d r .
\end{gathered}
$$

Having introduced notations

$$
\Psi_{n}(\alpha)=\int_{0}^{a} r J_{0}\left(\frac{\lambda_{n}}{a} r\right) J_{0}(\alpha r) d r
$$

from (22) we obtain

$$
\alpha^{2} B_{2}=\frac{\Delta(\alpha)}{c_{33}\left(s-s_{0}\right)} \sum_{n=1}^{N} a_{n} \Psi_{n}(\alpha)
$$

Substituting relation (23) into equation (18), we obtain

$$
u_{z}(r, 0)=m\left(s_{1}-s_{0}\right) \int_{0}^{\infty} \alpha^{2} B_{2} J_{0}(\alpha r) d \alpha=\frac{m\left(s_{1}-s_{0}\right)}{c_{33}\left(s-s_{0}\right)} \int_{0}^{\infty} \Delta(\alpha) \sum_{n=1}^{N} a_{n} \Psi_{n}(\alpha) J_{0}(\alpha r) d \alpha
$$

or

$$
u_{z}(r, 0)=k_{1} \sum_{n=1}^{N} a_{n} \int_{0}^{\infty} \Delta(\alpha) \Psi_{n}(\alpha) J_{0}(\alpha r) d \alpha
$$

In the last dependence the notation is introduced

$$
k_{1}=\frac{m\left(s_{1}-s_{0}\right)}{c_{33}\left(s-s_{0}\right)}=\frac{m_{1}\left(s_{1}-s_{0}\right)}{c_{44}\left(s-s_{0}\right)\left(1+m_{1}\right) l_{1} \sqrt{n_{1}}} .
$$


Requiring the fulfillment of the boundary condition (10) and taking into account relations (13) and (24), we find

$$
k_{1} \sum_{n=1}^{N} a_{n} \int_{0}^{\infty} \Delta(\alpha) \Psi_{n}(\alpha)\left\{J_{0}(\alpha r)-J_{0}(\alpha a)\right\} d \alpha=\omega^{*}(r)
$$

where

$$
\omega^{*}(r)=\left\{\begin{array}{l}
-\frac{1}{2 R}\left(r_{a}-a\right)^{2}, 0 \leq r \leq r_{a} ; \\
\frac{1}{2 R}\left[\left(r_{a}-r\right)^{2}-\left(r_{a}-a\right)^{2}\right], r_{a}<r \leq a .
\end{array}\right.
$$

Multiplying the relation (25) by $r J_{0}\left(\frac{\lambda_{q}}{a} r\right)$ and integrating the obtained expressions by $r$ from 0 to $a$, we have

$$
\begin{gathered}
\sum_{n=1}^{N} a_{n} \int_{0}^{\infty} \Delta(\alpha) \Psi_{n}(\alpha)\left[\Psi_{q}(\alpha)-K_{q} J_{0}(\alpha a)\right] d \alpha=\frac{w_{q}}{k_{1}}, q=\overline{1, N} \\
K_{q}=\int_{0}^{a} r J_{0}\left(\frac{\lambda_{q}}{a} r\right) d r ; \quad w_{q}=\int_{0}^{a} r \omega^{*}(r) J_{0}\left(\frac{\lambda_{q}}{a} r\right) d r .
\end{gathered}
$$

We introduce the notation

$$
a_{n}=\frac{1}{2 R k_{1}} a_{n}^{*} .
$$

Taking into of which account from (26) we obtain a system $N$ of linear algebraic equations with respect to unknowns $a_{n}^{*}$.

The expression for determining the focal parameter included in relation (27), we find from the equilibrium condition of the indenter

$$
2 \pi \int_{0}^{a} r \sigma_{z z}(r, 0) d r=-P
$$

Substituting in (28) expressions (21) and (27), we determine

$$
\frac{1}{2 R}=\frac{k_{1} P}{2 \pi} \frac{-1}{\sum_{n=1}^{N} a_{n}^{*} K_{n}}
$$


Taking into account (29), (27) from (21) we will have a formula for determining the distribution of contact stresses under the indenter

$$
\sigma_{z z}(r, 0)=-\frac{P}{2 \pi} \frac{\sum_{n=1}^{N} a_{n}^{*} J_{0}\left(\frac{\lambda_{n}}{a} r\right)}{\sum_{n=1}^{N} a_{n}^{*} K_{n}} .
$$

Based on relations (18) and (27) we find a formula for determining the vertical displacements of the points of the upper boundary plane of the layer

$$
u_{z}(r, 0)=-\frac{k_{1} P}{2 \pi} \frac{\sum_{n=1}^{N} a_{n}^{*} \int_{0}^{\infty} \Delta(\alpha) \Psi_{n}(\alpha) J_{0}(\alpha r) d \alpha}{\sum_{n=1}^{N} a_{n}^{*} K_{n}} .
$$

Numerical example. We analyze the influence of initial deformations on the level and nature of contact stresses and vertical displacements of the boundary plane of the layer in cases of compressible and incompressible material. As a numerical example, the case of the absence of a flat section at the base of the indenter is considered. Figures 1 and 2 show graphs of the function $\sigma^{*}=\frac{\sigma_{z z}(r, 0)}{P}$ that characterizes the distribution of contact stresses (30) at the pressure of the parabolic indenter on the layer lying without friction on a rigid base, for the presence in the layer of elastic potential of harmonic type (compressible bodies) and Bartenev-Khazanovich potential (incompressible bodies), and Figures 3 and 4 of function $u^{*}=\frac{u_{z}(r, 0)}{P}$, which characterizes the distribution of vertical displacements of the boundary plane of the layer (31).

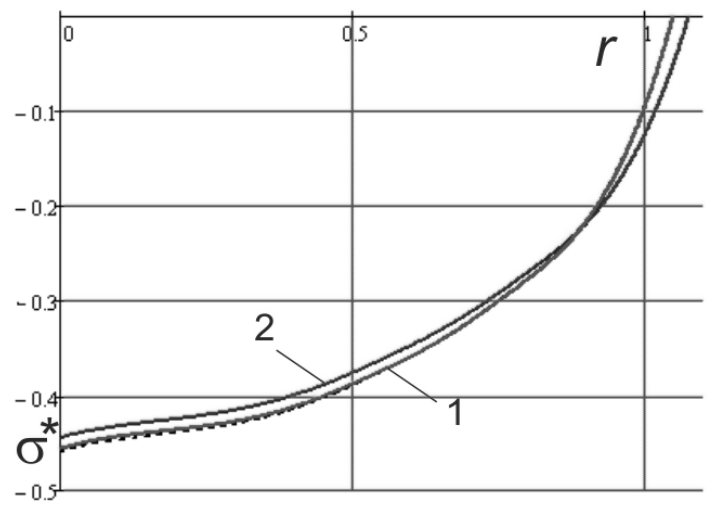

Figure 1. Contact stresses for the case of the harmonic-type potentia

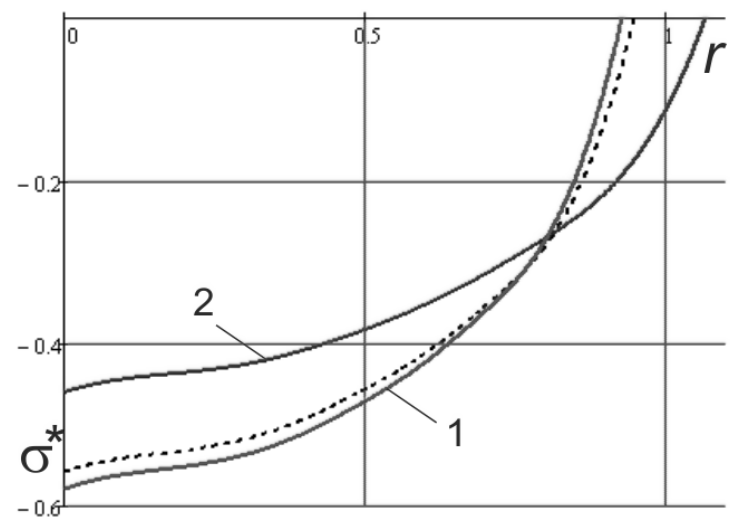

Figure 2. Contact stresses for the case of the Bartenev - Khazanovich potential 


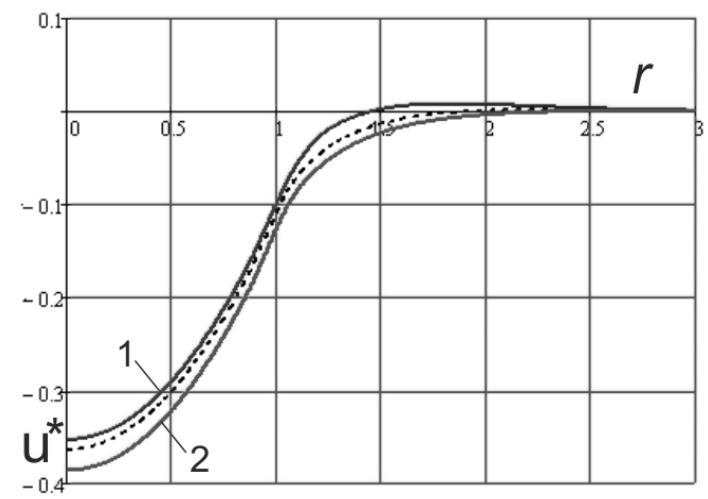

Figure 3. Vertical displacements for the case of the harmonic-type potential

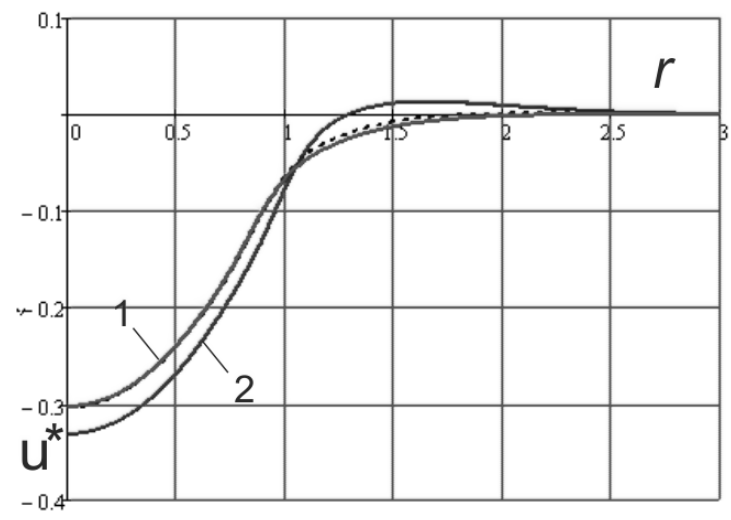

Figure 4. Vertical displacements for the case of the Bartenev - Khazanovich potential

The dotted curve in Figures 1-4 corresponds to the case of no initial deformations $\left(\lambda_{1}=1\right)$, curve 1 to the case of existing tensile deformations $\left(\lambda_{1}=1.2\right)$, and curve 2 to compression deformations $\left(\lambda_{1}=0.8\right)$.

Conclusions. After analyzing the obtained numerical results, it can be stated that in the case of contact with the prestressed layer, the residual tensile deformations cause an increase in the absolute value of the contact stresses and a decrease in vertical displacements. The presence of residual compression deformations causes a decrease in the absolute value of contact stresses and an increase in vertical displacements.

\section{References}

1. Mahesh S., Selvamani R., Ebrahami F. Assessment of hydrostatic stress and thermo piezoelectrici-ty in a laminated multilayered rotating hollow cylinder. Mechanics of Advanced Composite Structures. 2021. Volume 8. Issue 1. P. 77-86.

2. Jesenko M., Schmidt B. Geometric linearization of theories for incompressible elastic materials and applications. Mathematical Models and Methods in Applied Sciences. 2021. Volume 31. Issue 4. P. 829-860. DOI: https://doi.org/10.1142/S0218202521500202

3. Chen X., Dai H.-H., Pruchnicki E. On a consistent rod theory for a linearized anisotropic elastic material: I. Asymptotic reduction method. Mathematics and Mechanics of Solids. 2021. Volume 26. Issue 2. P. 217-229. DOI: https://doi.org/10.1177/1081286520949602

4. Babich S. Yu., Guz A. N., Rudnitskiy V. B. Kontaktnyie zadachi dlya uprugih tel s nachalnyimi napryajeniyami primenitelno $\mathrm{k}$ jestkim i uprugim shtampam. Prikl. mehanika. 2004. 40. No. 7. P. 41-69. [In Russsian]. DOI: https://doi.org/10.1023/B:INAM.0000046219.34646.4e

5. Habrusiev H. Habrusieva I., Shelestovs'kyi B. The effect of initial deformations of the thick plate on its contact interaction with the ring punch. Scientific Journal of TNTU. 2018. Vol. 90. No. 2. P. 50-59. DOI: https://doi.org/10.33108/visnyk_tntu2018.02.050

\section{Список використаної літератури}

1. Mahesh S., Selvamani R., Ebrahami F. Assessment of hydrostatic stress and thermo piezoelectrici-ty in a laminated multilayered rotating hollow cylinder. Mechanics of Advanced Composite Structures. 2021. Volume 8. Issue 1. P. 77-86.

2. Jesenko M., Schmidt B. Geometric linearization of theories for incompressible elastic materials and applications. Mathematical Models and Methods in Applied Sciences. 2021. Volume 31. Issue 4. P. 829-860. DOI: https://doi.org/10.1142/S0218202521500202

3. Chen X., H.-H. Dai, E. Pruchnicki On a consistent rod theory for a linearized anisotropic elastic material: I. Asymptotic reduction method. Mathematics and Mechanics of Solids. 2021. Volume 26. Issue 2. P. 217-229. DOI: https://doi.org/10.1177/1081286520949602

4. Бабич С. Ю., Гузь А. Н., Рудницкий В. Б. Контактные задачи для упругих тел с начальными напряжениями применительно к жестким и упругим штампам. Прикл. механика. 2004. 40. № 7. C. 41-69. DOI: https://doi.org/10.1023/B:INAM.0000046219.34646.4e 
5. Habrusiev H., Habrusieva I., Shelestovs'kyi B. The effect of initial deformations of the thick plate on its contact interaction with the ring punch. Scientific Journal of TNTU. 2018. Vol. 90. No. 2. P. 50-59. DOI: https://doi.org/10.33108/visnyk_tntu2018.02.050

\title{
УДК 539.3
}

\section{КОНТАКТНА ВЗАЕМОДІЯ ЗАЗДАЛЕГІДЬ ДЕФОРМОВАНОЇ ПЛИТИ, ЩО ЛЕЖИТЬ БЕЗ ТЕРТЯ НА ЖОРСТКІЙ ОСНОВІ 3 ПАРАБОЛІЧНИМ ШТАМПОМ}

\author{
Григорій Габрусєв; Ірина Габруссва
}

\section{Тернопільський нащіональний технічний університет імені Івана Пулюя, Тернопіль, Україна}

\begin{abstract}
Резюме. Продемонстровано розроблену методику побудови розв'язків осесиметричних задач визначення напруженого стану заздалегідь деформованої пружної плити при ї̈ контактній взаємодї з жорстким штампом. Співвідношення, щзо описують напружено-деформований стан тіл із початковими деформаціями, наведено у рамках лінеаризованої постановки задачі теорії пружності. Із використанням запропонованої методики досліджено напружено-деформований стан заздалегідь деформованої плити, щзо лежить без тертя на жорсткій основі під час ї̈ гладкої контактної взаємодї з жорстким осесиметричним параболічним цтампом складної конфігурації. Побудову аналітичних розв'язків контактної задачі для заздалегідь деформованої плити проведено шляхом ї̈ моделювання попередньо напруженим шаром. Граничні умови в зоні контакту сформульовано в класичній постановиі (відсутність дотичних напружень на граничній поверхні шару, відсутність нормальних напружень за межами зони контакту, вертикальність зміщення штампа). У результаті підстановки виразів для компонент напружено-деформованого стану плити в граничні умови побудовано систему двох інтегральних рівнянь, ядра яких містять функції Бесселя. Подаючи функцію розподілу контактних напружень під штампом у вигляді скінченного ряду за функиіями Бесселя, задачу зведено до скінченої системи лінійних алгебраїчних рівнянь відносно невідомих коефічієнтів ряду. Побудовано аналітичні вирази для контактних напружень та вертикальних переміщень межових точок плити. Застосувавщи отримані співвідношення проаналізовано вплив початкових деформацій на рівень та характер контактних напружень $i$ вертикальних переміщень межової площини плити у випадках стисливого та нестисливого матеріалів. Числовий аналіз проведено для випадків наявності у плиті пружного потенціалу Бартенєва - Хазановича, а також потениіалу гармонічного типу.
\end{abstract}

Ключові слова: заздалегідь деформована плита, попередньо напружений шар, контактні напруження, вертикальні переміщення, параболічний штамп, подвійні інтегральні рівняння. 